\title{
Redefining the concept of standardization for pluripotent stem cells.
}

\section{$\operatorname{AUTHOR}(\mathrm{S})$ :}

Sengoku, Shintaro; Sumikura, Koichi; Oki, Toshihiko; Nakatsuji, Norio

\section{CITATION:}

Sengoku, Shintaro ...[et al]. Redefining the concept of standardization for pluripotent stem cells.. Stem cell reviews 2011, 7(2): 221-226

\section{ISSUE DATE:}

2011-06

\section{URL:}

http://hdl.handle.net/2433/141343

\section{RIGHT:}

The final publication is available at www.springerlink.com; この論文は 出版社版でありません。引用の際には出版社版をご確認ご利用くださ $\iota_{\circ}$; This is not the published version. Please cite only the published version. 


\title{
Redefining the Concept of Standardization for Pluripotent Stem Cells
}

\author{
Shintaro Sengoku, Koichi Sumikura, Toshihiko Oki, Norio Nakatsuji
}

(C) Springer Science+Business Media, LLC 2010

\begin{abstract}
In this report we review the concept of standardization and propose an exhaustive framework for the proper management of technology on pluripotent stem cells based on studies of global and regional initiatives. We demonstrated detailed observational analysis on global initiatives for the standardization of related technologies as well as regional attempts with particular interest in the cases of the UK, the US and Japan. Consequently, we came up two fundamental issues: first, these initiatives and attempts tend to be limited to each of currently existing categories of pluripotent stem cells, whereas the technological opportunity to enable clinical/commercial application is equally open to all stem cell types. Second, the subject to be examined for standardization is set to a quite narrow range compared to precedent practices in other industrial sectors. To address these issues, we propose a strategic framework for standardization with an emphasis on comprehensiveness covering various technological opportunities and consistency to learning in the management science. By utilizing this framework development of intellectual property rights not only through patents but through taking leadership in standardization can be considered as means for improving research and development competence. Of particular concerns is the formation of quality standards for final products/services and core elemental technology, especially specific pluripotent stem cell lines. Furthermore, we inferred two stages of the standardization process, individualization where a particular product/service is qualified by the market, then standardization where the elemental technology is subsequently established as compatibility standards.
\end{abstract}

\section{Keywords}

Embryonic stem cell, Induced pluripotent stem cell, Intellectual property, Regenerative medicine, Standardization.

\section{Introduction}

In recent years, efforts have been made worldwide to standardize stem cell technology, including methods for cell characterization and unification of protocols [1]. Currently two significant initiatives for stem cell standardization were implemented at the International Stem Cell Forum (ICSF). One is the International Stem Cell Initiative (ISCI), which has reviewed the characteristics or criteria for human embryonic stem cell (hESC) lines [2, 3]. ISCI also considers the infrastructure development for stem cell research, in particular reliable basic research and clinical applications for hESCs. The other is the International Stem Cell Banking Initiative (ICSBI), which functions as an hESC lines bank and has set the minimum quality standard for hESC lines. The ICSBI has formed criteria to compare cell line data generated at different agencies around the world and constructed systems and guidelines for international transfer of hESC lines and 
other materials [4].

The UK is developing a forum for standardization. The UK Stem Cell Bank (UKSCB) was founded within the National Institute for Biological Standards and Control (NIBSC), which is responsible for the standardization of biopharmaceuticals. The UKSCB develops quality management technology for stem cells and implements tests for applied research in clinical settings; in particular, the UKSCB shows a strong international presence in terms of hESC lines by providing them free of charge.

Specific approaches can be seen in the application of basal technology for drug development. One example is Stem Cells for Safer Medicines (SC4SM) inaugurated in October 2007. SC4SMis a public-private consortium that developed toxicity testing technology for new chemical compounds as drug candidates utilizing stem cells [5]. Participating private organizations include three well-established European pharmaceutical companies: GlaxoSmithKline, AstraZeneca, and Hoffman-La Roche. Government-affiliated organizations include the UK Department of Health (DH), the UK Department for Business, Innovation and Skills (BIS), the Scottish Government, the Medical Research Council (MRC), and the Biotechnology and Biological Sciences Research Council (BBSRC).

In the US, investigations by an subcommittee with in the category F04 (Medical and Surgical Materials and Devices) at the American Society for Testing and Materials (ASTM) are under way, but universities and private sectors are leading the way in standardization. For example, the Wisconsin International Stem Cell (WISC) Bank and WiCell operated by University of Wisconsin is widely distributing hESCs. Geron Corp., a leading biotech company in regenerative medicine using hESCs, is presently planning a clinical trial to treat patients with spinal cord injury using the hESC H9 line, and the US Food and Drug Administration (FDA) has approved the trial. If the clinical trial is successful and hESC H9 is approved for medical application, it is likely that hESC and its investigations and/or approval by the FDAwill become a focal point for creating standards.

In addition, the Harvard Stem Cell Institute (HSCI) has worked in cooperation with GlaxoSmithKline to develop drug discovery infrastructure and disease mechanism research that targets cancer stem cell research and myocardial regeneration. In 2008, Pfizer launched a new center for stem cell research in Cambridge. Four major areas, including differentiating and inducing technologies for human hESCs and preparation of business models for autologous cultured cell therapy, are ready for research.

In Japan, efforts towards standardization are unique, focusing not on hESCs but on human induced pluripotent stem cells (hiPSCs). This is due to the excess regulation of hESC research [6, 7], as well as the fact that promising discoveries using hiPSCs has significantly raised expectations for hiPSCs in the country [8]. The Japanese Ministry of Education, Culture, Sports, Science and Technology has established the iPS Network, which is currently constructing a system to efficiently share research information and materials between organizations participating in projects associated with the ministry's hiPSC research.

\section{Issues and Necessity of Strategic Framework for Standardization}

As described above, there have been numerous attempts for standardization but some issues need to be resolved. One issue is the attempt to limit to each of currently existing pluripotent stem cell types. The goal in clinical practice is effective therapy, and to realize this goal, technology may not necessarily be limited to pluripotent stem cells. Thus, the framework of standardization needs to encompass stem cells, including somatic stem cells and fetal stem cells. Moreover, 
considering the lengthy time-span required for the realization of regenerative medicine, there must be provisions for the possibility of a totally new paradigm shift that overcomes development needs of the current pluripotent stem cells.

Another problem is that standardization issues have been narrowly approached. Most of the previous approaches were centered around evaluation methods for cell line characterization based on glycoanalysis, epigenomic analysis, genome analysis, and mRNA and protein expression analysis. These are a part of so-called lateral compatibility standard [9]. However, the concept of standardization normally includes other sub-concepts, for example, quality standards and vertical compatibility standards [9]. Quality standards are specifications for defining qualitative requirements for the final product/service. Examples of vertical compatibility standards are process technologies to couple basic and peripheral technologies, such as a method to reproducibly induce the same differentiated cells from different cell types or lines.

Common standardizations are de facto, forum/consensus, and de jure [10]. The de facto standard is the actual standard obtained by those with the dominant design through the marketing process. The de jure standard is determined by the proposal of a specification that is most commonly used in the market or the specification of quality. In addition to these, the consensus standard has gained attention in recent years [11]. These are standards based on the agreements of groups such as international forums and industry organizations.

To address these issues we propose the strategic framework shown in Table 1, with an emphasis on various technological opportunities and consistency in the management science. The immediate targets for consensus standardization are stem cell lines as product components, with an evaluation index and procedures for ensuring required quality. Because de facto is by definition formed as a result of marketing processes, and de jure criterion depends on the final product/service and is subject to different regulations in each country, these tend to be long-term measures.

However, in contrast to the semiconductor field, cell lines as a component of basic technology do not necessarily need to be merged into just 1 standard specification. Rather, it is believed to be ideal if multiple standard lines coexisted according to the objective or application. This is because the quality standard for cell lines is affected by the quality criteria for the final product/service. For example, safety would be of utmost importance for regenerative medical application, but not for pharmaceutical infrastructure technology application, because they are not applied to human body. In addition, cell lines need to be generated according to the good manufacturing practice (GMP) criteria for clinical use, but not necessarily for basic research.

\section{Potential Areas and Means of the Formation of Intellectual Property}

Acquiring intellectual property is defined as either obtaining a patent property for the subject technology (i.e., it is described in the claims of an approved patent), or the subject technology is included within the scope of rights of the patent property.

Stem cell-related technology is generally classified into several categories: basic technology for generation and maintenance of cell lines, technology for applications such as differentiation into specific cell types, analysis of cell characteristics, and modification of cells for medical purposes and administration to the human body [12]. A trend for ESCs has been that intellectual properties related to basic technology are possessed by a few organizations, whereas intellectual properties related to application are possessed by a large number of organizations of various nationalities, and the coverage of each patent is generally narrow [13]. 
Our exploration of existing and related patents confirmed the uneven distribution: 63, 53, and 86 of the related 219 patents are allocated to cell generation technology, maintenance, and differentiation, respectively, whereas only 7 patents have been dedicated to other applications (as of March 2010). An in-depth analysis of patents revealed that most are process patents narrowly limited to specific cell species and/or ways of cell modification and, thus, possibly insufficient for competing with new substitutive technologies.

Major patents related to the basic technology of ESCs are held by the Wisconsin Alumni Research Foundation (WARF) and this has been seen as a problem for the utilization and application of the intellectual property of stem cells $[13,14]$. The fundamental technology for hESCs was established at the University of Wisconsin. The patents related to these technologies have been granted to WARF, which owns human and simian ESCs and the cell generation methods for these cells (US Patent 5,843,780 for simian ESCs and its method for isolation, US Patent 6,200,806 for hESCs and its method for isolation and US Patent 7,029,913 for hESCs). On July 21, 2005, WARF also filed an application for human pluripotent stem cells (US patent application 20,050,158,854) as a continuation of US Patent 6,200,806.

These situations were expected to change with the establishment of hiPSCs in 2007, but regardless, intense competition resulted. One of the reasons for this is that claiming that iPSCs are compositions of matter is difficult. The characteristics of iPSCs are so difficult to differentiate from formerly established ESCs in both physical (e.g., surface antigens or gene expression patterns) and functional characteristics that the novelty of iPSCs seems to be difficult to be proven.

In fact, hiPSCs were the subject of a PCT application (WO2007/069666) by the inventor and the affiliated Kyoto University by claiming a relatively wide range of generation methods and the cell product itself. However, in Japan as of today, only the minimal claims of this application, which were the generation methods utilizing oct4, sox2, klf4, and $c-m y c$ genes, were filed as divisional applications in 2008 and patented (Japanese Patent No. 4,183,742). Moreover, patents related to establishment of iPSCs were filed by multiple organizations, each with different methods of production (e.g. Japanese Patent No. 4,411,362). The rights of these patents will be relatively narrow because they will be limited to the specific method of production. Further works on these issues are expected in future.

On the other hand, peripheral technology, such as instruments for culturing, evaluating, and manufacturing, can target a variety of stem cell types and result in a comparatively larger number of intellectual properties. It should be considered that the value of manufacturing technology cannot be maximized unless there is versatility for all cell types (i.e., vertical compatibility standard). In addition, there must be common criteria for evaluating the quality of cell products that can be applied to all cell types in order for it to function, and, in particular, comply with regulatory requirements (i.e., lateral compatibility standard).

From these considerations it is suggested that development of intellectual property rights not only through patents but through taking leadership in standardization be considered as means for improving research and development competence.

\section{Potential Areas of "Black Box" Instead of Patents}

Black boxes generally include technology and knowledge used for acquiring de facto standards, such as the architecture of the final product/service and manufacturing expertise, the technology to achieve maximum quality, and the data essential for the inspection of the standardization strategy. For example, even if an evaluation index for the quality 
evaluation of cells was excluded during the formation of the de jure or compatibility standards, if the index contributes to a higher quality than the competitor's, and if it also fulfills the market needs, it will become a competitive and useful technology. In addition, especially in regards to pluripotent stem cells, the industry is currently seeking technology that will facilitate large-scale production (Dr. S. Minger of GE Healthcare, personal communication). The so-called downstream technology from such manufacturing is essential for innovation, and will gain more attention in the future.

A pharmaceutical application of hES/iPSC-related technologies provides a case example describing the significance of black-box technologies. ReproCELL, Inc. is a biotech company founded in February 2003 in Tokyo. ReproCELL was established to productively use the accomplishments of stem cell research at the Institute for Frontier Medical Sciences, Kyoto University and the Institute of Medical Sciences, the University of Tokyo. Currently, the company's operations include sales of research reagents for ES/iPSCs, drug screening and toxicity tests using stem cells, and clinical diagnostics services.

For drug screening systems by using stem cells, a QT prolongation test called QTempo, which uses ESC/iPSC derived cardiomyocytes, was developed [15]. Because QT prolongation is correlated with myocardial toxicity, it is mandatory that regulatory authorities review its results. Resected animal hearts or cells are currently used for the tests. However, large quantities cannot be consistently provided, which has resulted in the high cost and long period of testing. The company, therefore, firstly developed QTempo from macaque ESC-derived cardiomyocytes. The preparation of cell samples in QTempo is easier compared to the conventional system, and a large amount of drug screening can be efficiently carried out. QTempo, now employing hES/iPSCs, provides a closer approximation to therapeutic reality.

Figure 1 shows the business system and key elemental technologies for QTempo. Focusing on patents, a composition patent was granted for the media used for culturing, but it is sold commercially and is readily available to everyone. Currently, there are also multiple methods proposed for inducing the differentiation of ESC/iPSCs into cardiomyocytes. It is only with high-throughput analysis that a unique technology is attempted. In other words, the contribution to value through the protection of rights by patents is limited.

Rather, QTempo's origin of value can be found in the improvement of the quality of its final product/service by organic linkage and in the integration of each of the elemental technologies of generation, maintenance, differentiation, and analysis. In fact, when the test results for QTempo were unfavorable, improvements made will extend to not only the method of analysis but possibly also to culture maintenance and differentiation, and selection of appropriate pluripotent stem cell lines.

\section{Standardization Process}

The standardization of pluripotent stem cell technology can be achieved in 2 stages: first, in an individualization stage where a particular product/service is firstly accepted by the market, and secondly, in a standardization stage where the technology at the core of the product/service is established as standard (Fig. 2). This is because the pharmaceuticals/ medical industry is regulated by different countries or regions. In order for pharmaceuticals/medical products/services to be distributed, criteria determined by regulatory agencies, such as FDA or European Medicines Agency (EMA), must be approved. Requirements for approval include, for example, manufacturing criteria as determined by GMP, and effectiveness/safety. Furthermore, all of these requirements correspond to the quality standards in the field of product/service. 
In the individualization process, several products/services driving innovation are emerging and are creating different standards of quality by the categories. Specifically, cardiomyocytes derived from hESC/iPSCs for drug testing are already commercially available; applications in regenerative medicine, such as treatment of spinal cord injury using hESCs, are under development; moreover, infrastructure technology for personalized medicine and hybrid medical instruments can also be expected (Dr. Yokoyama, C. of ReproCELL, Inc., personal communication).

The standardization process follows the individualization process. In the event that these products/services are successfully approved and marketed, stem cell lines, key technological elements such as predominant stem cell lines, and process/evaluation technology for ensuring required quality are expected to spill-over in phase with the expansion of the original product/service.

With regards to pluripotent stem cells, evaluation criteria with a central focus on hESCs are being developed, but the products/services in which they are used must be further examined in order to establish specifications. Although hiPSC standardization is being diligently reviewed, it should be considered carefully to establish consensus standards for cell lines because the possibility of novel reprogramming methodologies must also be envisioned. Instead, lateral/vertical compatibility that is not specialized for any particular cell type should be established. Specific examples include a means to effectively characterize identities or differences between different pluripotent stem cell types [16, 17] and the application of technology established in a particular pluripotent stem cell line to other cell types.

From the long-term perspective, creation of de jure standards, similar to other pharmaceutical/medical instrument fields, and harmonization of approval/investigation criteria between regulatory authorities are vital. In forming a consensus standard, global cooperation between groups promoting standardization and the industrial and corporate end-users needs to be intensified. In the formation of de facto standards, the aim should be to achieve the highest quality.

\section{Author information}

S. Sengoku*, N. Nakatsuji

The Institute for Integrated Cell-Material Sciences (iCeMS), Kyoto University, Yoshida-Ushinomiyacho, Sakyo-ku, Kyoto 606-8501, Japan e-mail: ssengoku@icems.kyoto-u.ac.jp

K. Sumikura

National Graduate Institute for Policy Studies (GRIPS), Tokyo, Japan

T. Oki

The Institute of Medical Science, the University of Tokyo (IMSUT), Tokyo, Japan

N. Nakatsuji

The Institute for Frontier Medical Sciences, Kyoto University, Kyoto, Japan

*Corresponding author

\section{Acknowledgment}

We thank Drs. Stephen L. Minger and Chikafumi Yokoyama for their insights and useful advices through interviews. We also thank government officials of Cabinet Secretariat and Ministry of Economy, Trade and Industry of Japan for critical suggestion. The case study was provided under cooperation with ReproCELL, Inc., Yokohama, Japan. This study was supported by World Premier International Research 
Center (WPI) Initiative from the Ministry of Education, Culture, Sports, Science and Technology of Japan (S. S. and N. N.)

\section{Conflict of Interest}

N. N. is a founder of ReproCELL, Inc. The authors report no conflict of interest, particularly no competing financial interest.

\section{References}

1. Loring, J. F., \& Rao, M. S. (2006). Establishing standards for the characterization of human embryonic stem cell lines. Stem Cells, 24(1), $145-150$.

2. Adewumi, O., Aflatoonian, B., Ahrlund-Richter, L., et al. (2007). Characterization of human embryonic stem cell lines by the International StemCell Initiative. Nature Biotechnology, 25, 803-816.

3. Akopian, V., Andrews, P. W., Beil, S., et al. (2010). Comparison of defined culture systems for feeder cell free propagation of human embryonic stem cells. In Vitro Cellular \& Developmental Biology - Animal, 46, $247-258$.

4. Crook, J. M., Hei, D., Stacey, G. (2010). The International Stem Cell Banking Initiative(ISCBI): raising standards to bank on, In Vitro Cellular and Developmental Biology - Animal, 46, 169-172.

5. Wadman, M. (2007). New tools for drug screening. Nature Reports Stem Cells, doi:10.1038/stemcells.2007.130.

6. Nakatsuji, N. (2007). Irrational Japanese regulations hinder human embryonic stem cell research. Nature Reports Stem Cells, doi:10.1038/stemcells.2007.66.

7. Kawakami, M., Sipp, D., \& Kato, K. (2010). Regulatory impacts on stem cell research in Japan. Cell Stem Cell, 6(5), 415-418.

8. Takahashi, K., Tanabe, K., Narita, M., Ichisaka, T., Tomoda, K., \& Yamanaka, S. (2008). Induction of pluripotent stem cells from adult human fibroblasts by defined factors. Cell, 131, 861-872.

9. Teece, D. J. (1986). Profiting from technological innovation: Implications for integration, collaboration, licensing and public policy. Research Policy, 15(6), 285-305.

10. Swann, G. M. P. (2000). The economics of standardization: final report for standards and technical regulations directorate. Manchester: University of Manchester Press.

11. Weiss, M., \& Cargill, C. (1992). Consortia in the standards development process. Journal of the American Society for Information Science, 43(8), 559-565.

12. Maherali, M., \& Hochedlinger, K. (2008). Guidelines and techniques for the generation of induced pluripotent stem cells. Cell Stem Cell, 3(6), 595-605.

13. Bergman, K., \& Graff, G. D. (2007). The global stem cell patent landscape: implications for efficient technology transfer and commercial development. Nature Biotechnology, 25, 419-424.

14. Vrtovec, K. T., \& Scott, C. T. (2008). Patenting pluripotence: the next battle for stem cell intellectual property. Nature Biotechnology, 26, 393-395.

15. Asai, Y., Tada, M., Otsuji, G., \& Nakatsuji, N. (2010). Combination of functional cardiomyocytes derived from human stem cells and a highly-efficient microelectrode array system: an ideal hybrid model assay for drug development. Current Stem Cell Research \& Therapy, 5(3), 227-232.

16. Kim, K., Doi, A., Wen, B., et al. (2010). Epigenetic memory in induced pluripotent stem cells. Nature, 467, 285-290.

17. Polo, J.M., Liu, S., Figueroa,M. E., et al. (2010). Cell type of origin influences the molecular and functional properties of mouse induced pluripotent stem cells. Nature Biotechnology, 28, 848-855. 
Figures and tables

Table 1 Proposed strategic framework for standardization of stem cell technology

\begin{tabular}{|c|c|c|c|}
\hline $\begin{array}{l}\text { Objective and approach } \\
\text { for standardization }\end{array}$ & De facto standard & Consensus standard & De jure standard \\
\hline \multirow[t]{2}{*}{ Quality standard } & \multirow[t]{2}{*}{ Final product/service } & \multirow{2}{*}{$\begin{array}{l}\text { Core component of product/ } \\
\text { service (e.g. stem cell lines) }\end{array}$} & Regulations (e.g. GMP) \\
\hline & & & $\begin{array}{l}\text { Regulatory guidelines for efficacy and } \\
\text { safety }\end{array}$ \\
\hline $\begin{array}{l}\text { Vertical compatibility } \\
\text { standard }\end{array}$ & $\begin{array}{l}\text { Process technology for } \\
\text { guaranteeing maximum quality }\end{array}$ & $\begin{array}{l}\text { Process technology for ensuring } \\
\text { required quality }\end{array}$ & $\begin{array}{l}\text { Process technology for ensuring } \\
\text { regulations/regulatory guidelines }\end{array}$ \\
\hline $\begin{array}{l}\text { Lateral compatibility } \\
\text { standard }\end{array}$ & $\begin{array}{l}\text { Evaluation technology for } \\
\text { guaranteeing maximum quality }\end{array}$ & $\begin{array}{l}\text { Evaluation technology for } \\
\text { ensuring required quality }\end{array}$ & $\begin{array}{l}\text { Evaluation technology for ensuring } \\
\text { regulations/regulatory guidelines }\end{array}$ \\
\hline
\end{tabular}


Fig. 1 Business system of ReproCELL's QTempo

\begin{tabular}{|c|c|c|c|c|}
\hline & $\begin{array}{l}\text { Receiving patient } \\
\text { tissue }\end{array}$ & $\begin{array}{l}\text { Generation of } \\
\text { pluripotent cell } \\
\text { strains }\end{array}$ & $\begin{array}{l}\text { Differentiation into } \\
\text { cardiomyocyte }\end{array}$ & $\begin{array}{l}\text { Measurement and } \\
\text { analysis of cardio- } \\
\text { toxicity }\end{array}$ \\
\hline Patent & & $\begin{array}{l}\text { - Composition of culture } \\
\text { medium }\end{array}$ & & $\begin{array}{l}\text { - High throughput } \\
\text { measurement } \\
\text { instrument } \\
\text { - Composition of } \\
\text { measurement medium }\end{array}$ \\
\hline $\begin{array}{l}\text { Tangible } \\
\text { asset }\end{array}$ & & $\begin{array}{l}\text { - Standard protocol } \\
\text { - Culture reagents such } \\
\text { as medium, } \\
\text { detachment solution. } \\
\text { and stock solution }\end{array}$ & - Standard protocol & $\begin{array}{l}\text { - Measurement } \\
\text { instrument (generic) } \\
\text { - Analysis software } \\
\text { (generic) }\end{array}$ \\
\hline Know-how & $\begin{array}{l}\text { Patient tissue } \\
\text { collection and } \\
\text { inspection } \\
\text { - Biological product } \\
\text { safety management }\end{array}$ & $\begin{array}{l}\text { Characterization of } \\
\text { obtained hES/iPSCS } \\
\text { - Cell strain selection } \\
\text { method } \\
\text { - Undifferentiated cell } \\
\text { culturing method }\end{array}$ & $\begin{array}{l}\text { Strain-dependent } \\
\text { differentiation method }\end{array}$ & $\begin{array}{l}\text { Differentiated cell } \\
\text { seeding method }\end{array}$ \\
\hline $\begin{array}{l}\text { External } \\
\text { network }\end{array}$ & & $\begin{array}{l}\text { - Supply agreement of } \\
\text { hESC strains } \\
\text { - Licensing agreement } \\
\text { with two academic } \\
\text { institutions }\end{array}$ & $\begin{array}{l}\text { - Licensing relationship } \\
\text { (differentiation } \\
\text { method) } \\
\text { - Advisory contract with } \\
\text { four experts }\end{array}$ & $\begin{array}{l}\text { - Patent / tangible asset } \\
\text { licensing agreements } \\
\text { from business } \\
\text { partners }\end{array}$ \\
\hline
\end{tabular}

Fig. 2 Proposed two stages approach for successful innovation with stem cell technology

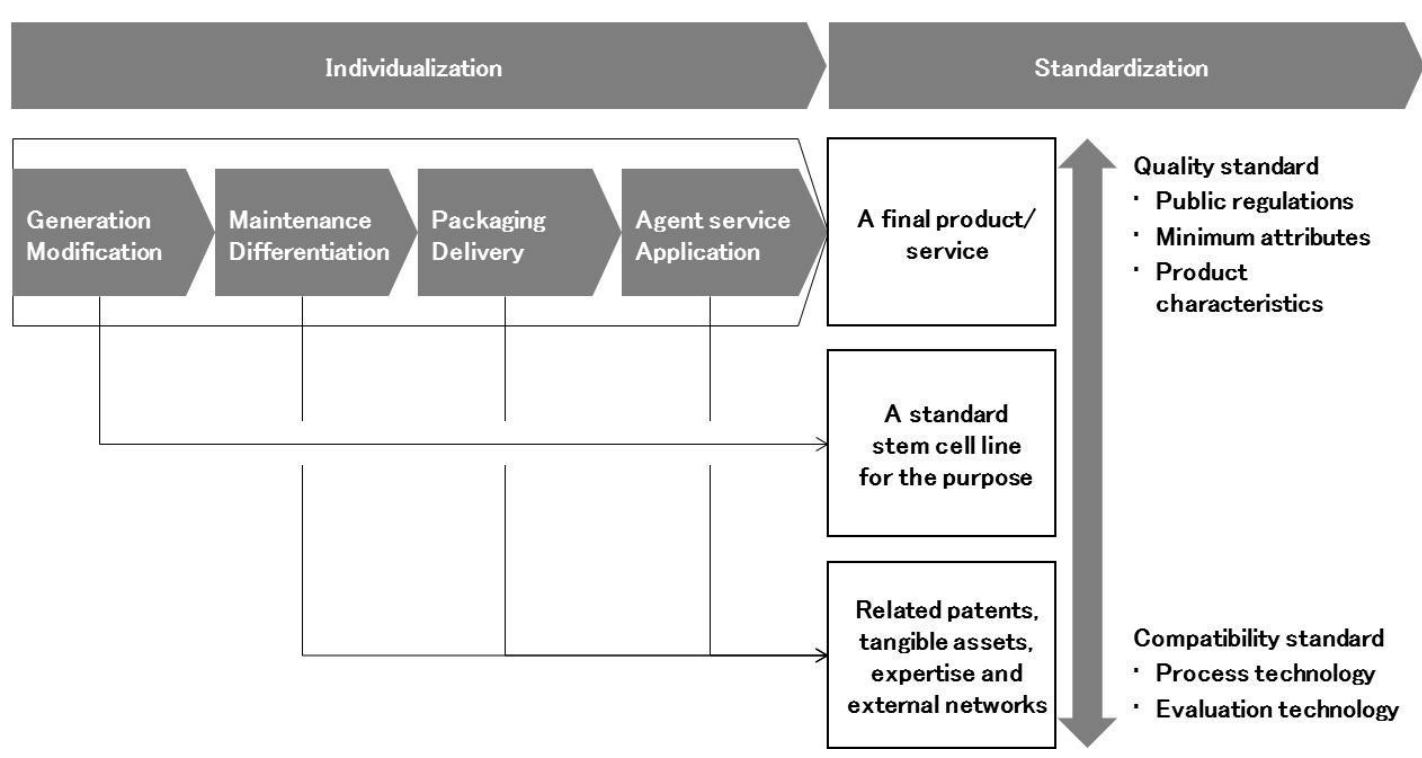

